\title{
Russian financial crisis
}

\author{
Lin Tan \\ International Business School \\ Yunnan University of Finance and Economics \\ Kunming, China \\ newannly@qq.com
}

Wei Zhou*

International Business School

\author{
Yunnan University of Finance and Economics \\ Kunming, China \\ zw453@163.com \\ Bingqing Ding \\ International Business School \\ Yunnan University of Finance and Economics \\ Kunming, China \\ 1446202654@qq.com
}

\begin{abstract}
All the countries of the world need a good environment to develop their economy, it is sad to see the recession of the financial crisis in recession. This paper aims to comprehensively study the Russian financial crisis in 2014 and find the reason of the phenomenon. And we hope warning those investors who want to do business around the world to avoid financial crisis from Russia.
\end{abstract}

Keywords -Russia; financial crisis; exchange rate; Western sanctions; oil

\section{INTRODUCTION}

With the development of the B\&R, Russia become really an important partner. It's no problem that studying Russia financial crisis is meaningful. Qi studied the future tend of Russia economy in the view of create new economy [1]. Gezegeer Franz W Keledeke studied reform in the financial crisis in the past 100years [2]. B. Popkov analysis the problem of banks during the period of reform [3]. Gao forecast the problem of which Russia financial conduction is not very good [4]. Putin in his "Russia's development strategy before 2020 " propose his viewpoint to reply the financial crisis of Russia [5]. Considering those research in the past, we think the new Russia financial crisis need a detailed study.

\section{RUSSIAN FINANCIAL CRISIS INTRODUCTION}

Russian financial crisis is an event which related to the rapid depreciation of the Russian ruble and a slowdown in economic growth of Russia in 2014. Russia experienced two events in 2014. On the one hand, as part of the Russian Crimea, Russia expanded its territory which can keep the strategic pivot, strengthened its control over the Black Sea and rise the unprecedented national cohesion; on the other hand, Since the civil war situation in the region led to unrest eastern Ukraine, the West national Joint sanctions against Russia. Considering a significant drop in international oil prices, the devaluation of the Russian ruble madness and a sharp decline in foreign exchange reserves, the net capital outflow in Russia in 2014 over 150 billion US dollars.

In January to November of 2015, the Russian economy to shrink by $4 \%$ year on year, highlighting its serious financial problems persist, despite Russia's economic crisis has peaked generated. The Russian National gross generation (GDP) of January to October fell by $3.7 \%$ per annul. In 2015 , Russia once again repeat the mistakes of 1998, facing difficulties of sovereign debt default. let's look at a chart 1.1 which shows an exchange rate between dollar and ruble.

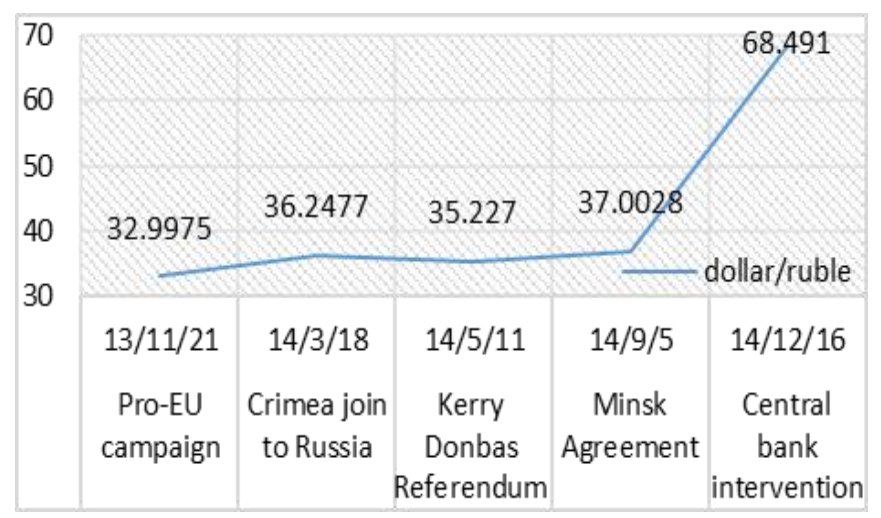

Figure. 1. The Russian ruble time

Source: USD to RUB Rates -Exchange Rates

There is a table showing corresponding data and event of the sequence in figure. 1 . And from this table, we could know that how the Russian ruble rate impacted by the big events in the past years. Also we could see which measures the Russia has taken to save their currency rate.

Although the fuse of Russian financial crisis is different to the previous financial crisis, but more dangerous, making painstaking efforts of the Russian economy shattered grand moment, that all of a sudden back to the economic level of 10 years ago. The world economic has slow down the pace of development and economic aspects of countries have appeared. Relying on IMF and few Western countries assistance, the Russian financial crisis in the past was able to get rid of, but it is clearly not possible to Russia rely on these two ways to solve their own problems again, thus resolving the financial crisis in Russia can be said to be difficult. At least the last two years, Russia would be in a difficult period of economic development.

\footnotetext{
* Corresponding author
} 


\section{RUSSIAN FINANCIAL CRISIS CAUSES}

\section{A. Weak consumer}

It owes to Weak consumer, dragged down real wages dropped by nearly $10 \%$ and raised the cost of debt payments. Russian businesses and residents to the country's financial institutions and local currency mistrust, that devaluation of the ruble, most residents choose to buy a lot of daily necessities in advance, but when the ruble continued to depreciate, they began selling rubles for foreign currency exchange to look forward to a more stable and more secure currency to hedge against inflation. The gradual emergence of the domestic market to be stagnant. Russia retail sales in October fell 13\% and in the first half of 2015 , it fell $8 \%$.

\section{B. Western sanctions}

Since Putin's forces against terrorism powerfully, Putin blockade to Turkey comprehensively. Civil war and the regional situation in the east of Ukraine led to unrest, combined with Western countries, sanctions on Russia. Because Turkey and the "Islamic State" secret collusion, Putin touched the interests of Turkey by anti-terrorist actions. Turkey's attitude completely angered Putin, Russia announced the implementation of a comprehensive embargo on Turkey as punishment. However, Turkey belongs to NATO, Russia has also been the EU's retaliation for the move. EU summit with Russia's decision to extend the six-month sanctions again until the end of July 2016, covering energy, finance and defense fields.

\section{Impact of the debt crisis in Ukraine}

Ukrainian did not plan to pay back their debt which make Russia's economy worse. IMF amended the rules permit in the case of sovereign debt default loans to the debtor in December 8th of 2014. As a result, even if Ukraine does not pay the debt to Russia, but also could he get IMF aid. In this way, the repayment which could ease Russian debt crisis, vanish into thin air

\section{International oil prices}

International oil prices have plummeted to make the Russian ruble under pressure, resulting in Russia rose $15 \%$ inflation, and low oil prices for most goods importing countries deflationary effect contrary. Europe, Russia's crude oil exports have been the main target now because the RussoTurkish controversy, the European Union has taken economic sanctions against Russia, of course, include restrictions on oil imports. International crude oil has always been oversupply situation, oil exports and is a major source of Russian finance.

At this point the United States announced the lifting of the ban on oil exports. To Russia, it is certainly not a small blow, and doubtless there will be more oil into the market, which will undoubtedly greatly reduce Russia's revenue, increased Russian debt default risk.

\section{E. The capital account}

It is an important reason for its fragile financial system that Russia open their capital account prematurely.In 1998, the ruble devaluation for the foreign capital withdrawal from the Russian financial market.But after the financial crisis in 1998 ,
Russia reform to reform financial system with a significant liberalization.In 2006, Russia canceled the restrictions under the capital account foreign exchange, in another word, nonresidents to buy and sell financial assets are no longer constrained. According to Mundell's theory - "impossible triangle", a fixed exchange rate regime when free capital flows, and once exchange rate impact international hot money, the central bank could not hedge the foreign exchange market which can only lead to a fixed exchange rate regime collapse. Make capital account liberalization prematurely can attract short-term international capital flows more frequently, but cause a lot of pressure free-floating ruble exchange rate.

\section{F. Commercial Banking System}

The vulnerability of the banking system is an important factor that conduct financial crisis from the financial markets to the real economy.Although Russia has been implementing higher interest rates, hoping to increase the savings rate. But the concept of household savings by restricting consumption habits, which high interest rates did not increase domestic savings rate.For stimulating invest, the stock market with limited savings are attracted to the stock market, while manufacturers generally face difficulties in financing difficulties. Due to the limited scale of the Russian commercial banks, most located in Moscow, St. Petersburg and other large cities.Russian commercial banks are mostly formed in the "shock therapy" period radical, growing up in the wave of privatization, and most banks gain from investing government bonds and foreign exchange market. However banks could not establish a branch structure by geographical restrictions. The source of their deposits is also relatively simple and weak anti-risk capability. When residents generally hold pessimistic expectation on the crisis, the bank while fall into crisis.

\section{RUSSIAN GOVERNMENT MEASURES}

In December 26, 2014, Putin said the government will certainly respond in a meaningful way the problems facing the overall economy and the country, but he ordered the Cabinet to abandon that is the New Year holidays in 2015, to deal with the economic crisis. Russia's anti-crisis main focus is locked in inflation and excessive unemployment, and to make concessions in terms of economic growth, which may be mainly based on three considerations: first, compared with the economic slowdown, inflation and unemployment is more a matter of the moment in Russia macroeconomic and stability of the whole of society, or that the main threat to Russia is more facing the global financial crisis. Second, while governance "stagnation" and "inflation" of course, is the ideal choice for best of both worlds, but Russia learn from the historical experience of the world economy, that the feasibility of a two-pronged reality does not exist. Measures listed below the Russian government to take the country by the financial crisis.

In December 15, 2014, Russia's foreign exchange reserves of nearly \$ 400 billion, is the world's sixth-highest. Russia's foreign exchange reserves have the ability to raise prices so that the value of the ruble, the same day, the Russian central bank spent nearly $\$ 2$ billion to try to stabilize the ruble. In December 16, 2015, the Russian central bank will lift interest 
rates economy 6.5 percentage points to 17 percent, but the measure failed to prevent a sharp decline in the ruble move, it sparked Russia may introduce capital controls speculation, leading to massive capital flight. Russian government asked five large state-owned exporters to sell their foreign currency deposits to ensure that by early March 2015 before the ruble exchange no more than the level at early October 2014, to support the ruble exchange rate.

\section{THE IMPACT Of THE RUSSIAN FINANCIAL CRISIS}

\section{A. Russian financial crisis on the Russian home}

The incident hit the Russian economy, producers and consumers received the loss, but also makes Russia negatively affected international trade. Russia's debt market has also been a huge influence. According to the Chinese Ministry of Commerce, the country's business report, January-March 2014, Russia's total amount of imports from major trading partners of \$ 61,169 billion. Russian central bank data show that on the 1 st of this month, Russia's foreign exchange reserves amounted to $\$ 373,658$ billion. As of November 1, the Russian Federation, the national debt was $\$ 53,704,600,000$, of which foreign debt due in 2015 only $\$ 2$ billion, while $70 \%$ will gradually expire between 2017-2043. Russia's economy will remain in recession until mid-2016, but since then economic growth will depend in part on consumer and business confidence could reverse the trend, if gas prices recover, and Western countries, the Russian economy can relax on manufacturing.

\section{B. Russian financial crisis on the world}

Ruble slump triggered turbulence in global financial markets, prompting investors to quickly transferred to highquality assets. The yield on 10-year German bonds fell to $0.56 \%$ for the first time issued. At the same time, the Japanese 10 -year bond yields as low as $0.36 \%$ of a record points. In December 15, 2014, Russia's foreign exchange reserves of nearly \$ 400 billion is the world's sixth-highest. Russia's foreign exchange reserves have the ability to raise prices so that the value of the ruble, the same day, the Russian central bank spent nearly $\$ 2$ billion to try to stabilize the ruble. FXCM forex trader at December 16, 2014 that, due to ruble price changes, which will be from the 17th US dollar against the ruble began trading restrictions. US dollar against the ruble market liquidity also declined substantially. Russian government asked five large state-owned exporters to sell their foreign currency deposits to ensure that by early March 2015 before the ruble exchange no more than the level at early October 2014, to support the ruble exchange rate.

Russian debt or other assets held by the relatively high amount of the financial institutions affected by the Russian financial crisis. Almost all options are worthless. By the end of September 2014, the Pacific Investment Management Company (PIMCO) emerging market bond funds have $21 \%$ invested in Russian corporate bonds and sovereign debt, the net value of the Fund November 16, 2014 - between December 2014, 16 May has depreciated by $7.9 \%$.

\section{CONCLUSION}

After analysis the Russian financial crisis, we could make these conclusions. One important reason for the financial crisis of 2014, crude oil prices fell, while crude oil is one of the important Russian export goods, its price in between June 2014 to the date of December 16 fell by almost half. And the impact is sweep the world of which the Russia financial crisis.

Another important reason for the financial crisis is Russia's financial sector is not developed, but the financial institutions but everywhere arisen. Currently commercial banks in Russia, about 1800 , of which more than half of its total assets below $\$$ 150,000. These commercial banks to solicit depositors high interest rates is mainly engaged in the financial markets and speculation. Now Russia's commercial banks non-performing loans accounted for about $50 \%$ of its total assets ratio, although the assets of commercial banks have insurance mechanisms to protect, but the actual ability of insurance companies to pay insurance estimates can only reach about $50 \%$ of assets to cope.

Although Western countries still adopt economic sanctions against Russia, but if the center of effective financial regulation, guidance can be made to ease the crisis by analyzing the guidance, timely forecasting potential crises professionals.

\section{ACKNOWLEDGMENT}

My deepest gratitude goes first and foremost to Professor Zhou, my supervisor, for his constant encouragement and guidance. Without his consistent and illuminating instruction, this thesis could not have reached its present form. And my thanks would go to my beloved family and friends for their loving considerations and great confidence in me all through these years.

\section{REFERENCES}

[1] W.H. Qi, "Innovative Economy: Economic Development Road for Transitional New Approach - A Study of Russia," vol. 06, Russian, East European and Central Asian Studies, 2007, pp. 48-56.

[2] G.W. Keledeke, "post-eleven from shock therapy to the Socialist Transition After the political and economic," 2008.

[3] B. Popkov, "Transformation in the bank," Financial Times, 2010, pp 60-78.

[4] Z. Gao, "After the financial crisis of the Russian banking industry and revelation," Heilongjiang Provincial Academy of Social Sciences, 2015, pp. 9-11.

[5] V.V. Putin, "Russia's development strategy before 2020," 2015.

[6] L. Bobo, "Axis of Convenience: Moscow, Beijing, and the New Geopolitics,” Brookings Institution Press and Chatham House, 2009.

[7] J. Falchi, "Russia's economy shrank 3.7\%," Financial Times, January 2016.

[8] F. Jack, "Peter Spiegel, Brussels, Russia consider the establishment of 'bad banks'," Financial Times, November 2015.

[9] X. Ji, "Russia Review of the international financial crisis measures," vol. 9, Russian, East European \& Central Asian Studies, pp. 13-16, April 2009.

[10] R. Kagan, "History's Back: Ambitious Autocracies, Hesitant Democracies," vol. 8, Weekly Standard, pp. 10-16, December 2008.

[11] N. Buckley, and K. Hille, "Russia slid financial crisis".

[12] V.V. Putin, "Putin's Collected Works Beijing," vol. 8, China Social Sciences Publishing House, 2008, pp. 676 -677. 
[13] L. Shao, "From the Russian-Georgian conflict to the international financial crisis, 'a crisis of political economy' - Change of relations among major powers Russia and Its Implications for China,” vol. 9, Russian Studies, pp. 70-88, June 2009.

[14] C. Wei, "Russia's economic performance and its anti-crisis Policy of the world financial crisis," vol. 10, World Economics and Politics, pp. 121159 , September 2010
[15] X. Xin, "The Russian financial crisis and its impact," vol. 98, International Economic Review, pp. 51-54, December 1998

[16] J. Yu, "International strategic outlook Mistakes and Russia's future," vol. 15, knowledge of the world, pp. 35-37, February 2015. 